\title{
Developing Mathematical Literacy Task in Multiplication and Division of Algebraic Expression
}

\author{
Novita Sari ${ }^{1, *}$ Novika Sukmaningthias ${ }^{2}$ Zuli Nuraeni ${ }^{3}$ Ruth Helen Simarmata ${ }^{4}$ \\ Uswatun Hasanah ${ }^{5}$ Khairani Nasya Anggraini ${ }^{6}$
}

\author{
1,2,3,4,5,6 Mathematics Education Department, Universitas Sriwijaya, Indonesia \\ *Corresponding author. Email: novitasari@fkip.unsri.ac.id
}

\begin{abstract}
This study aims to produce mathematical literacy tasks in multiplication and division of algebra expression which is valid and practical for grade 7. This product was developed through development research with formative evaluation from Tessmer. The formative evaluation involves two stages, preliminary and prototyping. In this study, the prototyping phase comprises self-evaluation, expert reviews as well as one-to-one, and small groups. There were three experts who validated the content, context, and language of the tasks and total of eight students in grade 8 of SMP Negeri 40 Palembang as the research subject for one-to-one and small groups. Walk through, interview, and documentation was used to collect data. Data collections, in the form of interview result, comments, suggestions, and documents of students' answers, were analyzed descriptively. This study produced mathematical literacy tasks in multiplication and division of algebra expression for grade 7, which are valid through validation from expert review as well as one-to-one and practical from the small groups. Furthermore, this mathematical literacy tasks can be implemented by teacher or other researcher in the class in order to know the effectiveness and the potential effect which are given.
\end{abstract}

Keywords: Mathematical literacy, Development research, Algebraic expression.

\section{INTRODUCTION}

The fast-flowing development of information and technology is identified as 21 st century where many routine and repetitive works are being replaced by technology like production machines and computers. The computer will substitute for each work in performing manual and cognitive tasks because each work requires information rapidly, and computers can process information quickly [1], [2]. When a lot of routine work can be done by computers, today's work demands are no longer on how to use mathematical calculations but more on how we understand a system and how to develop it. This is an important concern for the world of education to prepare a generation that has 21 st-century abilities, namely solving complex problems, thinking critically, arguing, communicating, and collaborating in future work. Mathematical literacy can be the solution as the component to promote 21 st-century skills [3], [4].
Mathematical literacy is unlimited to the skill of applying mathematics counting but encompasses knowledge of mathematics in broad understanding [5]. Mathematical literacy is simply meaning as the knowledge of how to know mathematics and apply it in everyday life. Furthermore, The Organization for Economic Corporation and Development (OECD) develops a broader meaning of mathematical literacy. Mathematical literacy is an individual's capability to formulate, use, and interpret mathematics in various contexts that help individuals to recognize the role of mathematics in world and to make the judgments and reasoned decisions needed by engaged and reflective citizens [6]. Mathematical literacy includes seven basic mathematical abilities, namely: (1) communication; (2) mathematizing; (3) representation; (4) reasoning and argument; (5) devising strategies for solving problems; (6) using symbolic, formal, and technical language and operations; and (7) using mathematical tools [6]. 
In the 2013 curriculum, there are five objectives of learning mathematics in primary to secondary schools. They are capable of: (1) understanding mathematical concepts; (2) using patterns as conjectures and solving problems, making generalizations based on existing phenomena or data; (3) using reasoning on properties, performing mathematical manipulations both in simplification, as well as analyzing existing components in problem solving in the context of mathematics as well as outside mathematics; (4) Communicating ideas, reasoning, and constructing mathematical proofs (5) having an attitude of appreciating the use of mathematics in life; (6) having an attitude and behaviour that is according to the values in mathematics and learning; (7) performing motor activities that use knowledge of mathematics; and (8) using aid tools [7]. There are similarities between the eight basic mathematical skills in mathematical literacy and the objectives of learning mathematics in the 2013 Curriculum in Indonesia. It can be said that the goal of learning mathematics to be achieved in Curriculum 2013 is mathematical skills in mathematical literacy.

In the 2013 Indonesian Curriculum, mathematical literacy is one of the competency areas for graduates needed to face future challenges. However, the mathematical literacy ability of Indonesian students currently is low. The 2018 Programme for International Student Assessment (PISA) assessment reports that Indonesia ranks 72 from 78 countries. In mathematics, the average score of Indonesian students end up at 379 while the OECD average score of 487 [8]. A Previous study concerning students' mathematical literacy also showed that it is very low with algebraic content was in a low category [9].

Based on the analysis of content standards for junior high school mathematics subjects in the 2013 Curriculum, the number of Basic Competencies for algebraic material is more than other materials. Algebra is one of the contents that is often discussed in PISA problems encompassing algebraic expressions, algebraic properties, equations, and inequalities [10]. Algebra is also necessary to be mastered because knowledge and skills of algebra are also related to daily life either immediately or as a precondition. However, research on student literacy in simplifying algebraic expressions shows that students have fluency in routine questions of simplifying algebraic expressions, but not for non-routine questions and story questions [11]. In fact, to measure students' literacy skills, of course, through the provision of mathematical literacy tasks appearing as real-world problems. It is because mathematical literacy starts from realistic problems [12]. Learners must be promulgated to the two mathematical content and real-life contexts. Furthermore, mathematical content is required to understand real-life contexts whereas context determines the required content [13].

Unfortunately, mathematical literacy tasks are rarely given to students during learning. Students are used to getting explanations, formulas, and rote theories. The fact is that there are a small number of instructional instruments that can contribute to the development of them. This can be seen from the learning assessment whose substance does not equip students to become skilled at literacy [14]. Based on the analysis of algebraic material questions in the published student math textbooks by Balitbang grade VII semester 1 revised edition 2018, it was found that the problem of mathematical literacy specifically for multiplication and division operations was still small. If students are not familiarized with mathematical literacy problems, students' mathematical literacy skills are difficult to develop.

From the facts described, the development of mathematical literacy tasks on multiplication and division of algebraic expressions is a need so that it helps teachers in learning. Moreover, it is equally essential that the mathematical literacy task developed can provide students a space to practice and develop their mathematical literacy skills. Therefore, this research is urgent to be carried out due to the limitations of mathematical literacy tasks, especially in the material of multiplication and division of algebraic expressions that are useful as a means for students to practice mathematical literacy skills and achieve the objectives of mathematics learning in the 2013 curriculum.

The objective of this study is to produce mathematical literacy tasks in multiplication and division of algebra expression for grade 7 that meet valid and practical criteria. This tasks will be used as the instruments for further research about mathematical literacy skill and can be used by mathematics teachers to teach about algebra material in the class. This product in the form of developing mathematical literacy tasks has several limitations, such as the material is limited to multiplication and division of algebraic expression and the product may not be optimal due to short of period of time as well as online learning situations during the pandemic. 


\section{METHOD}

\subsection{Research Design}

The type of this study is development research. It encompasses two stages, namely preliminary and prototyping. The prototyping phase includes selfevaluation, expert reviews as well as one-to-one, small group, and a field test [15]-[17]. However, this paper only discusses up to the small group stage in order to examine whether the mathematical literacy task in multiplication and division of algebra expression for grade 7 developed is valid and practical. The following are the stages of development carried out:

\subsubsection{Preliminary Stage}

At the preliminary stage, several investigations and literature reviews were carried out to prepare for the development of mathematical literacy tasks in multiplication and division for grade 7. After that, an initial prototype was designed based on investigation results and literature review.

\subsubsection{Preliminary Stage}

At the prototyping stage, the initial prototyping was self-evaluated then revised became the first prototyping. Three experts validated the first prototyping in terms of content, construct, and language. At the same time, the one-to-one phase was arranged to evaluate particularly on what obstacles the students face and how they understand the information and solving the tasks. From suggestion in these stages, first prototyping revised to second prototyping. In small group, the second prototyping was organized. This stage is done to see the practicality of developed tasks. The preliminary stage was conducted through Zoom Meeting Conference and Whatsapp.

Based on Nieveen's valid criteria, content validity is that components of mathematical literacy tasks must be based on up-to-date knowledge (using context, can develop basic mathematical skills in mathematical literacy) while the construct validity is that components must relate to each other consistently. If the intervention meets these requirements, it is considered valid. Practicality means that it is usable with intervention in the normal conditions of learning.

\subsection{Research Subject}

The total research subject were seven students grade 8 of SMP Negeri 40 Palembang, in detail two students (high and low level) as subject in the one-toone stage and 6 students (high, medium, and low level) as subject in the small groups stage. Student grade 8 was chosen with consideration that they had been learned about multiplication and division algebra expressions.

\subsection{Data Collection and Analysis}

Data collection techniques used in this research were walkthrough, interview, and documentation. Documentation was conducted to collect initial data related to mathematical literacy skills, multiplication and division in algebra expression, and other related literature. Interview is used to analyse the needs of this development. The walk through was carried out at the expert review, one-to-one, and small group stages. Data collection in the form of documents, comments, suggestions, and test results were analyzed descriptively.

\section{RESULTS AND DISCUSSION}

The development process carried out broadly includes the preliminary stage and the prototyping stage. The preliminary stage resulted in the initial design of mathematical literacy tasks in multiplication and division algebra expression called initial prototyping. The prototyping stage, namely expert review as well as one-to-one, resulted the first prototype then the second prototype was obtained after the small group. This article will specifically discuss 2 tasks that have been developed.

\subsection{Preliminary}

In the preliminary stage, several steps were conducted. The first step was conducting needs analysis, curriculum analysis, and students analysis.

The needs analysis was conducted by interviewing the mathematics teachers at SMP Negeri 40 Palembang. The results are that the teachers want to improve students' mathematical literacy skills, the experience of teachers in making or developing mathematical literacy skills is minimal, and teachers rarely give math literacy tasks to students. In the student analysis, the research subjects are between the ages of 11-13 years. Based on the theory of cognitive development by Jean Piaget [18], this age range is in the formal operational stage. They began to experience a transition period from the use of concrete operations to the application of formal operations. In the curriculum analysis, the curriculum used is the curriculum 2013. The material for multiplication and division of algebraic expressions is included in the basic competencies of 3.5 and 4.5, namely, explaining algebraic expressions and performing operations on 
algebraic expressions (addition, subtraction, multiplication, division) and solving problems related to algebraic expressions and operations on algebraic expressions. The prerequisite materials are namely: (1) algebraic expressions, addition and subtraction of algebraic forms; (2) area and perimeter of squares and rectangles. The indicators of competency achievement are performing multiplication operations on algebraic forms, performing division operations on algebraic forms, and solving contextual problems related to operations of multiplication and or division of algebraic forms.

The second step was to design an initial prototype along with its rubric scoring. The last step was determining validators and research subjects where three validators and students grade 8 of SMP Negeri 40 Palembang.

\subsection{Prototyping}

The prototyping stage encompassed selfevaluation, expert review and one-to-one, small group, and field test. For this study, a field test was excluded.

\subsubsection{Self-Evaluation}

For self-evaluation, authors examined through discussing the initial prototype relating to content, construct, and language. Afterward, the initial prototype was revised became the first prototype.

\subsubsection{Expert Review and One-to-One}

The first prototype was validated by experts and tested on two students in a one-to-one phase. Validators of this study were three experts. They were Elika Kurniadi, S.Pd., M.Sc. and Ambarsari Kusuma Wardani, M.Pd. Currently Elika Kurniadi, S.Pd, M.Sc. now engaged in mathematical modeling research as it is known that mathematical modeling is part of mathematical literacy. Ambarsari Kusuma Wardani, S.Pd. has conducted some research about PISA problems which has assess mathematical literacy. In addition, another validator is Mellyana, S.Pd., M.M. as a mathematics teacher who has a lot of experience in learning. These experts reviewed the first prototype in the matter of content, construct, and language. In a one-to-one phase, the researcher conducted trials with 2 students in grade 8 at different times through a zoom meeting. Tasks that are given to students can be seen as follow.

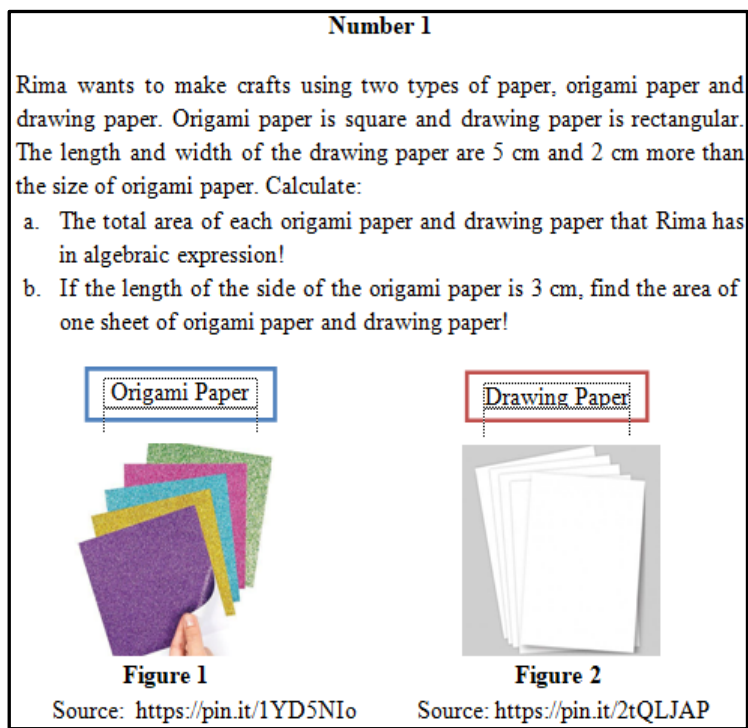

Figure 1 The first prototype of number 1.

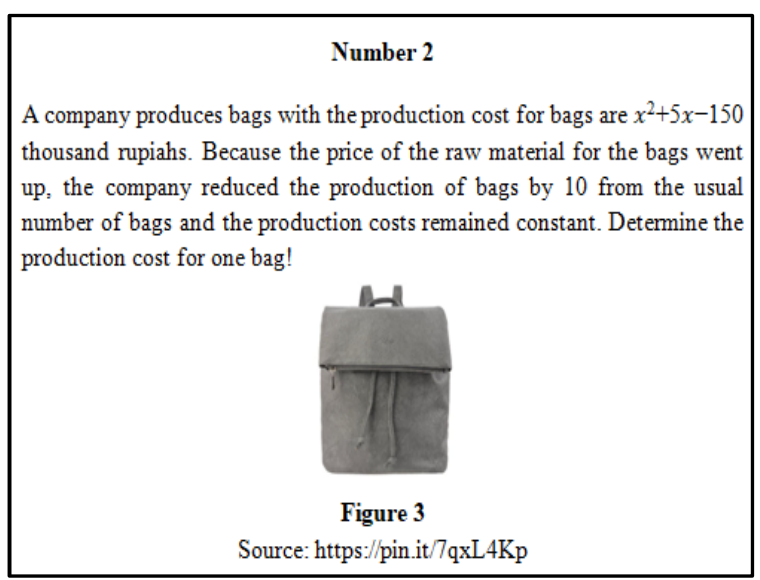

Figure 2 The first prototype of number 2 .

Figure 1 and 2 shows the first prototype of mathematical literacy tasks about multiplication and division of algebra expression consecutively. It can be seen from the Figure 1 and 2 that both of tasks using contextual problem. The context used in the Figure 1 is about making craft using origami paper and drawing paper. For the Figure 2, the production cost for bags is used as a context.

The comments obtained through the walk-through during the expert review and one-to-one along with the revision decisions can be seen in Table 1 . 
Table 1. Comments from experts as well as students and revision decisions

\begin{tabular}{|c|c|c|c|}
\hline $\begin{array}{l}\text { Task } \\
\text { Number }\end{array}$ & Phase & Comments & Revision Decisions \\
\hline \multirow[t]{4}{*}{1} & \multirow[t]{2}{*}{$\begin{array}{l}\text { Expert } \\
\text { Review }\end{array}$} & $\begin{array}{l}\text { Has the area and perimeter material been given to } \\
\text { students in grade } 7 \text { for odd semesters? Try to } \\
\text { analyze the curriculum again }\end{array}$ & $\begin{array}{l}\text { Area and perimeter have been } \\
\text { studied in elementary school so } \\
\text { that it does not matter given to } \\
\text { students in grade } 7 .\end{array}$ \\
\hline & & $\begin{array}{l}\text { Is it okay to use square material in the problem? It is } \\
\text { because the material is taught in chapter } 8\end{array}$ & $\begin{array}{l}\text { Square material has been learned in } \\
\text { elementary school grade } 6 \text { and it is } \\
\text { still used in the task. }\end{array}$ \\
\hline & \multirow{2}{*}{$\begin{array}{l}\text { One-to- } \\
\text { One }\end{array}$} & I quite understand number 2 & - \\
\hline & & I don't understand what "more than" means. & $\begin{array}{l}\text { The word "more than" changed to } \\
\text { "more than the side length of" }\end{array}$ \\
\hline \multirow[t]{6}{*}{2} & \multirow[t]{4}{*}{$\begin{array}{l}\text { Expert } \\
\text { Review }\end{array}$} & $\begin{array}{l}\text { The form of the quadratic equation is not quite } \\
\text { right, if } x \text { is } 10 \text {, then how much will the production } \\
\text { cost of } 10 \text { bags be? }\end{array}$ & \multirow{2}{*}{$\begin{array}{l}\text { The context is changed to the } \\
\text { living room area and the kitchen } \\
\text { area }\end{array}$} \\
\hline & & $\begin{array}{l}\text { Context is not properly presented to } 7 \text { th graders, } \\
\text { because it seems that they do not understand the } \\
\text { term production. It's better to look for a simpler } \\
\text { problem for the topic of dividing algebraic forms }\end{array}$ & \\
\hline & & $\begin{array}{l}\text { After the revision it doesn't matter if the new case } \\
\text { used, but it is added by visualizing the image }\end{array}$ & Adding figure \\
\hline & & $\begin{array}{l}\text { It is better not to present the quadratic function } \\
\text { equation first }\end{array}$ & $\begin{array}{l}\text { The quadratic function does not } \\
\text { appear in the problem }\end{array}$ \\
\hline & \multirow{2}{*}{$\begin{array}{l}\text { One-to- } \\
\text { One }\end{array}$} & It is hard how much rupiah minus 10 bags & \multirow{2}{*}{$\begin{array}{l}\text { The context is changed to the living } \\
\text { room area and the kitchen area }\end{array}$} \\
\hline & & It is very hard to understand & \\
\hline
\end{tabular}

These comments given are used as input to revise the first prototype. Task number 1 was slightly revised while task number 2 was completely changed. The revised tasks were declared valid from experts and called as the second prototype. The second prototype was shown in Figure 3 and Figure 4.

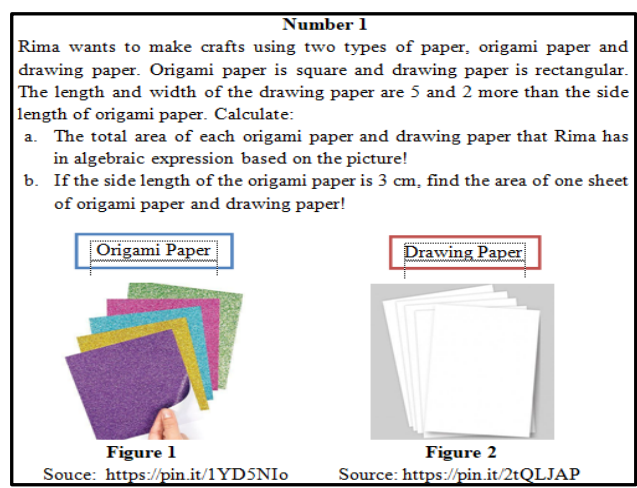

Figure 3 The second prototype of number 1 .

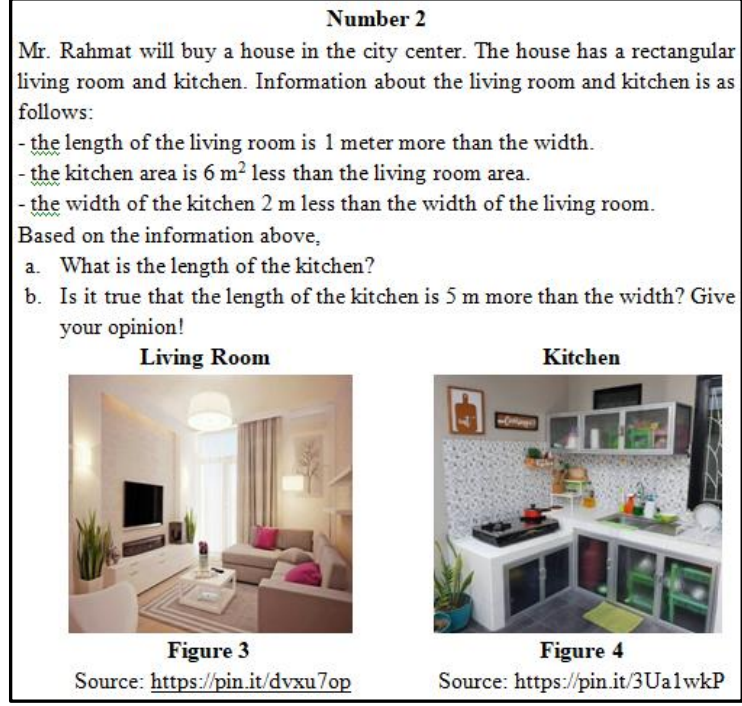

Figure 4 The second prototype of number 2 . 


\subsubsection{Small Group}

At this stage, the second prototype was tested on six of 8th grade students of SMP Negeri 40 Palembang which were carried out through a zoom meeting screen. Before working on the problem, students are reminded again about the elements of algebra, operations on algebraic expressions, the material for the area and perimeter of squares and rectangles, and discuss world problems. The aim is to refresh the facts, concepts, principles, and procedures of algebra material that they have learned in grade 7. The use of mathematical literacy tasks in multiplication and division algebra at the small group stage shows that this can be said to be practical even though the comments from students are convoluted sentences. Furthermore, the tasks were revised again but not all student comments were used as material for revising. Based on information from their mathematics teacher, online learning since last year has prevented students from learning optimally so that students' competence cannot be said to be high. This is felt by researchers when zooming in, students often turn off videos so that teachers cannot control whether students are actively participating in learning or not. After receiving comments from students on this small group stage, the second prototype was revised to become the third prototype which is practical.

\section{CONCLUSIONS}

This study produced a set of mathematical literacy tasks in multiplication and division of algebra expression for grade 7 which is valid and practical. Valid is generated through reviewing from experts and one-to-one while practical based on small group implementation. The value from this development is that multiplication and division of algebra expression material can be presented as mathematical literacy task without algebra expression in the given world problem. It also can give insight and inspiration for other teachers and practitioners to develop mathematical literacy task. Lastly, suggestions for teachers and other practitioners are that they can use this task or even develop it to train mathematical literacy, especially in multiplication and division of algebra material.

\section{ACKNOWLEDGMENTS}

The authors would like to thank Universitas Sriwijaya for funding this research through DIPA of Public Service Agency of Universitas Sriwijaya 2021 with SP DIPA-023.17.2.677515/2021, on November 23,2020 . In accordance with the Rector's Decree
Number: 0007/UN9/SK. LP2M.PT/2021, on April 27, 2021.

\section{REFERENCES}

[1] B. F. Levy, How technology changes demands for human skills, OECD Education Working Papers No. 45 (2010) 1-18. DOI: https://doi.org/10.1787/19939019

[2] M. Goos, A. Manning, and A. Salomons, Explaining job polarization: routine-biased technological change and offshoring, American Economic Review 104(8) (2014) 2509-2526. DOI: 10.1257/aer.104.8.2509

[3] A. Wijaya, Students' information literacy: A perspective from mathematical literacy, Journal on Mathematics Education 7(2) (2016) 73-82. DOI: $10.22342 /$ jome.v7i2.3532

[4] H. Julie, F. Sanjaya, and A. Y. Anggoro, The mathematics education department students' ability in mathematical literacy for uncertainty problems on PISA adaptation test, AIP Conf. Proc. 1366 (2017). DOI: 10.1088/1742$6596 / 1366 / 1 / 012082$

[5] J. De Lange, Mathematics for literacy, in quantitative literacy: why numeracy matters for schools and colleges, in: B. L. Madison and L. A. Steen (Eds.), Princeton, NJ, National Council on Education and the Disciplines, 2003, pp. 75-89.

[6] OECD, PISA 2018 mathematics framework, in: PISA 2018 Assessment and Analytical Framework, OECD Publishing, Paris, 2019, pp. 73-95.

[7] Kemdikbud, Lampiran III Peraturan Menteri Pendidikan dan Kebudayaan Nomor 58 Tahun 2014 Tentang Kurikulum 2013 SMP/MTs, Jakarta, 2014, pp. 325-327.

[8] OECD, PISA 2018 Results, Combined Executive Summaries, vol. I, OECD Publishing, Paris, 2019.

[9] Rifai and D. U. Wutsqa, Kemampuan literasi matematika siswa SMP Negeri se-Kabupaten Bantul, Jurnal Pendidikan Matematika dan Sains 5(2) (2017) 152-162. DOI: 10.21831/jpms.v5i2.15747

[10] OECD, PISA 2021 Mathematics Framework (Draft), OECD Publishing, Paris, 2018.

[11] F. Mujulifah, Sugiatno, and Hamdani, Literasi matematis siswa dalam menyederhanakan ekspresi aljabar, Jurnal Pendidikan dan Pembelajaran 4(1) (2015) 1-12. [Online]. Available: 
http://jurnal.untan.ac.id/index.php/jpdpb/article/ view/8766

[12] W. Oktiningrum, Zulkardi, and Y. Hartono, Developing PISA-like mathematics task with Indonesia natural and cultural heritage as context to assess students' mathematical literacy, Journal on Mathematics Education 7(1) (2016) 1-8. DOI: $10.22342 /$ jme.7.1.2812.1-8

[13] F. Machaba, Approaches to mathematical literacy tasks : findings from a study involving mathematics and mathematical literacy, in: Towards Effective Teaching and Meaningful Learning in Mathematics, Science and Technology. Proceedings of the 6th International Conference on Mathematics, Science and Technology Education (IST), Unisa Press, Mopani Camp in Kruger National Park, Limpopo, South Africa, 2016, pp. 149-162.

[14] S. Wardhani and Rumiati, Instrumen Penilaian Hasil Belajar Matematika SMP: Belajar dari PISA dan TIMSS, Pusat Pengembangan dan Pemberdayaan Pendidik dan Tenaga Kependidikan (PPPPTK) Matematika, Yogyakarta, 2011.

[15] M. Tessmer, Planning and Conducting Formative Evaluations, Kogan Page, Londan, 1993.

[16] Zulkardi, Developing A Learning Environment On Realistic Mathematics Education For Indonesian Student Teacher (Doctoral disertation, University of Twente, Enschede), University of Twente, 2002.

[17] T. Plomp, Educational Design Research: an Introduction, in: T. Plomp and N. Nieveen, (Eds.), An Introduction to Educational Design Research, Enschede: SLO, Netherlands institute for curriculum development, 2007, pp. 9-35.

[18] M. F. Joubish and M. A. Khurram, Cognitive development in Jean Piaget' $s$ work and its Iimplications for teachers, World Application Science Journal 12(8) (2011) 1260-1265. 